\title{
Organizing the Voice of Women: A Study of the Polish and Swedish Women's Movements' Adaptation to International Structures
}

\author{
Eva Karlberg \\ Stockholm: Södertörns högskola 2019 \\ 257 sider. ISBN 9789188663818
}

Omtalt av Kirsti Stuvøy [ph.d., førsteamanuensis ved Noragric, Norges miljø- og biovitenskapelige universitet (NMBU), kirsti.stuvoy@nmbu.no]

Polen er ett av de landene der kvinnesak og likestilling i de siste åra er på retur. Den konservative regjeringens anti-likestillingstiltak, som å forsøke å forby abort eller å fremme et ultra-konservativt syn på kvinner og LHBT, har fått mye oppmerksomhet, blant annet i Norge. Polen har dessverre selskap av andre stater, som for eksempel Ungarn, og er eksempel på en internasjonal anti-likestillingstrend. I kontrast til denne utviklingen har Sverige satt internasjonal dagsorden med feministisk utenrikspolitikk. I et internasjonalt perspektiv på kvinner og likestilling framstår Sverige og Polen dermed som to verdimessige ytterpunkt.

I doktorgradsavhandlingen "Organizing the voice of women. A study of the Polish and Swedish women's movements' adaptation to international structures» tar Eva Karlberg for seg betydningen av internasjonale strukturer for kvinnebevegelsen, og sammenligner disse to landene. Sammenligningen har til formål å belyse hvordan sosiale bevegelser nasjonalt reagerer, omorganiserer, tilpasser og opplever ulemper og fordeler ved å etablere fellesorganisasjoner. Europeisering er konteksten for studien. EU har søkt å finne én stemme til å representere sivilsamfunnet, for å unngå mangfoldet av stemmer og synspunkt. Det er et godt valg å se på kvinnegrupper i denne sammenheng. Selv om det tradisjonelt er saker kvinner enes om, som stemmerett og kamp mot vold mot kvinner, rommer kvinnegrupper et mangfold av moralske og politiske synspunkt. EUs fokus på én stemme synliggjør et strukturelt perspektiv på demokrati der et mangfold skal forenes i nasjonale kvinnepolitiske interessefellesskap. Det statlige fellesskapet naturliggjøres, og som jeg skal komme tilbake til seinere, er denne EU-tilnærmingen også et uttrykk for et spesifikt syn på kvinners politiske fellesskap. 
I avhandlingen har Karlberg undersøkt erfaringene til kvinnebevegelsen i Sverige og Polen med å etablere meta-organisasjoner, altså en sentralisert kvinnelobby, for å utvikle relasjoner til EUs flernivå-system (multilevel system of governance). Forskningsspørsmålene handler om motivene for etableringen av en slik kvinnelobby i de to landene, hva som fremmet eller hemmet etableringen, og hvilke utfordringer og fordeler en slik organisering har for sosiale bevegelser. Jeg leser denne forskningen som basert på to premisser. For det første betraktes utviklingen av en nasjonal kvinnelobby i de to landene som en reaksjon på den ytre strukturen, altså EU. For det andre er det ikke likestillingens innhold eller kvinners aktivisme som står i fokus: Kvinnelobbyen er interessant for å undersøke betydningen av organisatorisk form i møte med en enhet høyere opp i det overnasjonale hierarkiske systemet som flernivåstyringen er. Sammenligningen av Sverige og Polen får fram to ulike erfaringer med forsøk på samorganisering. Som allerede antydet over, får analysen en slagside der de politiske verdiene og normene som står på spill for og i kvinnebevegelsen i dette systemet får lite plass. Kvinnelobbyen får analytisk fokus i betydningen av at de er representanter for nasjonale interesser for nasjonale kvinner.

Boka er velstrukturert og har åtte kapitler. I innledningen presenteres rammen for studien, det vil si EU-systemet og rollen sivilsamfunnet har i det, samt kvinnebevegelsen som case. Deretter presenteres det teoretiske rammeverket, der Karlberg utvikler et perspektiv på sosiale bevegelser som forskjellig fra organisasjoner. Sistnevnte utgiør en bestemt orden, en hierarkisk og ufleksibel orden, mens sosiale bevegelser er et sosialt rom ("social space») der kollektiv handling og ny kunnskap utvikles, prosessuelt og i stadig endring. Disse to organisasjonstypene skaper konstante spenninger. Empirisk retter studien blikket mot hvordan kvinnebevegelsene i de to landene jobbet for å lage en meta-organisasjon som kan representere kvinnebevegelsen som én stemme mot EU. Hvordan feltarbeidet ble gjort og hvilke data som er brukt beskrives i et eget metodekapittel. Et eget kapittel er viet kvinnebevegelsens historie i Sverige og Polen, og i analysen sammenlignes motiver for meta-organiseringen, betydningen av ressurser for denne, og spenninger innad i kvinnebevegelsen.

I analysen blir det tydelig hvor forskjellige de to kvinnelobbyene er. Den svenske kvinnelobbyen fikk en framtredende rolle, ikke bare som talerør vis-a-vis EU, men også i FN-systemet, der de formidlet den svenske modellen for kjønnslikestilling. For de svenske kvinnene forelå det en organisasjonsmodell (Riksförbundet), og denne gjorde de bruk av for å etablere seg. De dro også nytte av støtte fra den svenske regjeringen og de hadde ressurser tilgjengelig.

For den polske kvinnelobbyen var det problemer med interesse og tillit. De håpet kontakt med EU ville gi dem økt legitimitet til å jobbe for kvinner og likestilling i Polen. Tradisjonen med store kvinneorganisasjoner i sovjet-tiden bidro ikke til å vekke interessen for en meta-organisasjon, snarere til uvilje. Et annet typisk trekk ved det polske sivilsamfunnet som hemmet etableringen av en kvinnelobby, var konkurransen om utenlandsk støtte. Dette førte til mange organisasjoner, som var små og uten medlemmer, og til konkurranse om de tilgjengelige midlene. Den polske 
kvinnelobbyen ble da heller ikke etablert som en meta-organisasjon. I stedet ble den opprettet som et underbruk av en annen organisasjon, som et særskilt prosjekt.

En av fordelene med meta-organisering er enhet. Som Karlberg selv påpeker har det også ulemper fordi det visker ut pluralisme, ulike meninger og brytninger innad i en organisasjon. I analysen forklares det godt og nyansert hvordan dette førte til utfordringer i de konkrete casene som er studert. Det legges vekt på hvordan meta-organisering fremmet konkurranse blant medlemsorganisasjonene, og også mellom meta-organisasjonen og medlemsorganisasjonene. Det førte også til undergraving av tilliten til meta-organisasjonene. I EU som flernivåsystem var det behov for én motpart, og ikke rom for mange partnere. Dette bidro til kamp om å få tilgang til det internasjonale nivået.

Karlberg får godt fram hvordan flernivåstyring i EU skaper spenninger vis-a-vis sivilsamfunnet, som presses inn i én form. Konklusjonen er at slik meta-organisering må brukes forsiktig og med respekt for lokale forhold. Samtidig holdes metaorganisering på nasjonalt nivå opp som svar på globalisering. EUs hierarkiske strukturering av én stemme for kvinnebevegelsen på nasjonalt nivå skaper et skille til det internasjonale nivå. Studien fremmer, uten å problematisere det, en idé om kvinners felles nasjonale interesser. Den internasjonale kvinnebevegelsen kommer ut av syne, og med det blant annet bevisstheten om klasse og rase som viktige faktorer for å formulere (ulike) kvinners interesser. En sentral kvinnepolitisk spenning i dag gjelder på den ene siden motsetningen mellom den liberale feminismens fokus på å stadig knuse glasstaket slik at kvinner også kan bli del av den globale eliten, og på den andre siden den radikale feminismen som retter blikket mot underpriviligerte, marginaliserte og fattige kvinner og deres hverdagslige utfordringer. Disse spenningene går på tvers av skillet mellom nasjonal og internasjonal politikk. På et eller annet sted i denne forskningen har dette blitt utdefinert. Det er synd, for slik kunne forskningen bidratt bredere enn det den gjør til spørsmål om kvinnebevegelsen og aktivisme i lys av globalisering og demokrati. 